\title{
GAMBARAN PELAKSANAAN PROTOKOL COVID-19 PADA CIVITAS FAKULTAS KEPERAWATAN UNIVERSITAS RIAU DI ERA NEW NORMAL
}

\author{
Dwi Apri Kurniawan ${ }^{1)}$, Erika ${ }^{2)}$, Rismadefi Woferst ${ }^{3)}$ \\ ${ }^{12}$ Fakultas Keperawatan, Universitas Riau \\ Email: dwi.apri5329@student.unri.ac.id
}

\section{Diterima: Desember 2021, Diterbitkan: Desember 2021}

\begin{abstract}
Abstrak
Protokol Covid-19 adalah suatu aturan yang sesuai dengan standar ketentuan kesehatan yang sudah ditetapkan dalam rangka mencegah pandemi Covid-19. Penelitian menggunakan desain deskriptif bertujuan menggambarkan pelaksanaan protokol Covid-19 pada civitas Fakultas Keperawatan Universitas Riau. Sampel penelitian adalah civitas Fakultas Keperawatan Universitas Riau yang kebetulan ada di lingkungan fakultas dengan teknik accidental sampling dengan sampel 100 orang. Hasil penelitian menunjukkan responden yang tidak mencuci tangan sebelum masuk fakultas 66 orang (66\%) dan yang tidak mencuci tangan setelah berkunjung dari fakultas 68 orang (68\%). Responden yang memakai masker, menutup hidung, dagu dan mulut saat berada di fakultas 95 orang (95\%). Responden yang memakai masker menutup hidung, dagu dan mulut saat berinteraksi 95 orang (95\%). Responden yang tidak bersalaman/berciuman/ berpelukan saat bertemu dengan civitas lainnya 100 orang (100\%), jaga jarak fisik 1-2 meter 97 orang (97\%). Responden yang tidak berkumpul-kumpul di lingkungan fakultas 97 orang (97\%), responden yang meninggalkan area kampus setelah selesai kegiatannya 100 orang (100\%). Responden yang tidak berbagi makanan atau minuman pribadi 100 orang $(100 \%)$, Responden yang tidak meminjam alat tulis, buku dan perlengkapan pribadi lainnya 99 orang (99\%). Pelaksanaan protokol Covid-19 pada civitas Fakultas Keperawatan Universitas Riau di Era New Normal sudah cukup baik namun belum optimal di pelaksanaan cuci tangan sebelum masuk ke lingkungan fakultas dan setelah berkunjung dari lingkungan fakultas. Hasil penelitian ini diharapkan menjadi referensi tentang penerapan atau pelaksanaan protokol Covid-19.
\end{abstract}

Kata kunci: Protokol Covid-19, civitas Fakultas Keperawatan Universitas Riau

\begin{abstract}
The Covid-19 health protocol is a role that is carried out in accordance with established health regulatory standards in order to prevent the Covid-19 pandemic. This study employed a descriptive design aimed at describing the implementation of the health protocol of Covid-19. The research sample was the members of the Faculty of Nursing, the University of Riau who happened to be around the faculty with an accidental sampling technique totaling 100 people. The measuring instrument was in the form of an observation sheet. The result showed 66 people (66\%) did not wash their hands before entering the faculty area, 68 people (68\%) did not wash their hands after visiting the faculty area. 95 people (95\%) wore a mask, covering the nose, chin, and mouth while in the faculty area. All of them (100\%) did not shake hands/ kiss/ hug when meeting with other members of the community. 97 people (97\%) of them were not in groups in the faculty area. All of them left the faculty area immediately after completing their activities (100\%). All of them (100\%) also did not share personal food or drinks. Almost all of them (99\%) did not borrow stationery, books, and other personal equipment. The implementation of the health protocol of the Covid-19 in the Faculty of Nursing at the University of Riau in the New Normal Era has been quite good. However, the health protocol has not been optimal in the implementation of washing hands before and after visiting the faculty area. The results of this study are expected to become a reference for the application or implementation of the Covid-19.
\end{abstract}

Keywords: Covid-19 health protocol, civitas Faculty of Nursing, Riau University 


\section{PENDAHULUAN}

Coronavirus Disease 2019 (Covid19) muncul pertama kali di Wuhan, Hubei, China pada tanggal 29 Desember 2019 (Komisi Kesehatan Nasional RRC, 2020). Pemerintah setempat kemudian mengkonfirmasikan kasus tersebut kepada WHO. Selang beberapa hari kemudian penyebab penyakit ini sudah teridentifikasi yaitu novel coronavirus 2019. Penyebaran penyakit yang cepat dan tingkat kematian yang tinggi maka WHO menyatakan penyakit ini sebagai pandemi dunia (WHO, 2020). Pemerintah Indonesia juga sudah mengatakan Covid-19 ini sebagai bencana nasional (PDPI, PERKI, PAPDI, PERDATIN \& IDAI, 2020).

Penyakit Covid-19 ini dapat menyebabkan gangguan pernapasan akut dengan gejala demam, batuk, sesak napas serta berprognosa menyebabkan pneumonia, sindrom pernapasan akut dan gagal ginjal (DitJen P2P, 2020). Penyakit ini menginfeksi saluran pernafasan dan berdasarkan pengurutan genetika, virus ini berjenis betacoronavirus yang terkait erat dengan virus SARS (CDC China, 2020). Masa inkubasi penyakit ini rata-rata 5-6 hari dengan masa inkubasi terpanjang yaitu 14 hari dengan prognosa komplikasi terburuk sampai dengan kematian (Kemenkes RI, 2020).

WHO (2020) menginformasikan bahwa ada dua cara utama penularan virus Covid-19 ini, yaitu melalui percikan (droplet) saluran pernapasan dan melalui kontak. Penularan Covid-19 terjadi melalui 2 transmisi yaitu melalui transmisi kontak dan melalui transmisi droplet atau percikan yang keluar saat seseorang batuk atau bersin, tertawa dan pada saat bicara melalui sekret saluran napas (Burhan, 2020). Pencegahan penularan Covid-19 dimasyarakat dengan menerapkan Physical distancing, menjaga kebersihan tangan, menerapkan etika batuk dan bersin, memakai masker dan pembatasan aktivitas diluar rumah (Kemenkes RI, 2020).

WHO mencatat sampai dengan tanggal 24 Januari 2021 total kasus terkonfirmasi sebanyak 97.464.094 kasus dengan 2.112.689 kematian (CFR 2,2\%) dimana kasus dilaporkan telah menjangkiti 222 negara dan 184 negara yang terjangkit transmisi lokal termasuk Indonesia. Jumlah kasus terkonfirmasi di Indonesia menurut PHEOC Kemenkes RI tanggal 24 Januari 2021 sebesar 989.262 kasus dengan rincian kasus meninggal sejumlah 27.835 (2,8\%), kasus sembuh berjumlah 798.810. Kasus dengan spesimen diperiksa sejumlah 5.848.960 dengan kasus suspek yang masih dipantau sebanyak 80.114 dan kasus negatif sebanyak 4.859.698 kasus (Kemenkes RI, 2020).

Jumlah keseluruhan kasus Covid-19 di Kota Pekanbaru berdasarkan data dari Dinas Kesehatan Provinsi Riau pertanggal 24 Januari 2021 tercatat sebanyak 13.214 orang dengan rincian isolasi mandiri 469 orang, rawat di RS 222 orang dan meninggal 296 orang. Sedangkan untuk kasus suspek Covid-19 berjumlah 9.966 kasus, isolasi mandiri 604 orang, isolasi di RS 23 orang, selesai isolasi 9.276 orang dan kasus meninggal sebanyak 63 orang (Dinkes Provinsi Riau, 2021).

Hasil penelitian Cahyorini (2020) yang berjudul pengetahuan, sikap dan perilaku hidup sehat masyarakat dalam menghadapi pandemi Covid-19 di Indonesia didapatkan persentase pengetahuan, sikap dan perilaku tentang cuci tangan pakai sabun dengan baik dan benar sebesar $70,67 \%$, perilaku aktivitas fisik seperti berolahraga selama 30 menit sehari masih rendah yaitu sebesar $21,2 \%$, persentase responden yang keluar rumah tanpa pakai masker sebesar 5,3\% serta $66,4 \%$ responden setuju bahwa melaksanakan himbauan dirumah saja dapat mengurangi penyebaran virus Covid19 ini. Hasil penelitian Wulandari dkk (2020) dengan judul hubungan karakteristik individu dengan pengetahuan pencegahan Coronavirus Disease 2019 pada masyarakat di Kalimantan Selatan menunjukkan tidak ada hubungan status pekerjaan dengan pengetahuan tentang pencegahan Covid-19. 
Fakultas Keperawatan Universitas Riau sebagai salah satu penyelenggara pendidikan keperawatan berkomitmen untuk membantu pemerintah mensukseskan pemutusan mata rantai penyebaran Covid-19 dengan melakukan upaya-upaya preventif. Upaya preventif seperti dengan terlihatnya fasilitas dan sarana untuk cuci tangan pakai sabun dengan air mengalir disetiap ruangan serta menyediakan hand sanitizer. Fakultas Keperawatan Universitas Riau juga membuat panduan-panduan atau teknis pelaksanaan yang mengarahkan para civitas untuk bisa menerapkan protokol Covid-19 di lingkungan Fakultas Keperawatan Universitas Riau.

Pelaksanaan protokol Covid-19 di Fakultas Keperawatan Universitas Riau sendiri mengacu pada peraturan Dekan Fakultas Keperawatan melalui surat pemberitahuan No. 367/UN19.5.1.1.10/EP/2020. Berdasarkan surat tersebut diharapkan bagi civitas Fakultas Keperawatan agar dapat menerapkan beberapa hal diantaranya anjuran untuk hidup sehat dengan menjaga konsumsi makanan, mencuci tangan, menyediakan hand sanitizer, istirahat yang cukup jika mengalami gejala influenza dan kurangi interaksi bila merasa kurang sehat, menunda bepergian ke luar negeri terutama ke negara yang terdampak Covid-19, menggunakan masker dan mengurangi aktivitas di keramaian, segera ke fasilitas kesehatan bila mengalami demam, batuk dan kesulitan bernafas, menghindari kontak langsung dengan penderita demam dan batuk, menghindari menyentuh mata, hidung dan mulut, tutup mulut dan hidung saat batuk dan bersin dengan tisu. Peraturan tersebut sejalan dengan tujuan penelitian untuk mengetahui gambaran pelaksanaan protokol Covid-19 pada civitas Fakultas Keperawatan Universitas Riau di era new normal dalam rangka menjaga dan melindungi para civitas Fakultas Keperawatan Universitas Riau dari penularan Covid-19.
Berdasarkan fenomena masih adanya kegiatan dan aktivitas civitas Fakultas Keperawatan di lingkungan fakultas, maka penulis tertarik untuk melakukan penelitian bagaimana gambaran pelaksanaan protokol Covid-19 pada civitas Fakultas Keperawatan Universitas Riau di era new normal.

\section{METODOLOGI PENELITIAN}

Desain penelitian ini menggunakan desain deskriptif, yaitu penelitian yang bertujuan untuk menggambarkan pelaksanaan protokol Covid-19 yang meliputi pelaksanaan cuci tangan sebelum masuk kelingkungan fakultas dan setelah berkunjung dari fakultas, memakai masker, menjaga jarak fisik, menghindari kerumunan dan menghindari berganti-ganti alat dan perlengkapan pribadi pada civitas Fakultas Keperawatan Universitas Riau di era new normal.

Lokasi penelitian dilaksanakan dan dilaksanakan di Fakultas Keperawatan Universitas Riau. Awal mulanya syarat penelitian ini yaitu prariset di bulan Agustus 2020 dan pelaksanaan semua kegiatan baik riset sampai seminar hasil bertepatan pada bulan bulan Maret 2021 . Sampel penelitian adalah dengan teknik accidental sampling dengan sampel 100 orang.

Analisis data dalam penelitian ini digunakan untuk mengetahui gambaran karakteristik responden dan gambaran tentang pelaksanaan cuci tangan, memakai masker, jaga jarak fisik dan menghindari kerumunan dan menghindari atau tidak berganti-ganti alat dan perlengkapan pribadi.

\section{HASIL PENELITIAN}

Hasil penelitian tentang gambaran karakteristik responden civitas Fakultas Keperawatan Universitas Riau pada saat dilakukan pengamatan adalah sebagai berikut: 
Tabel 1. Karakteristik responden berdasarkan jenis kelamin.

\begin{tabular}{lcc}
\hline \multirow{2}{*}{ Jenis kelamin } & Frekuensi & Persentase \\
\cline { 2 - 3 } & $\mathbf{( n )}$ & $\mathbf{( \% )}$ \\
\hline Laki-laki & 33 & 33 \\
Perempuan & 67 & 67 \\
Total & 100 & 100 \\
\hline
\end{tabular}

Berdasarkan tabel 1 maka diketahui bahwa jumlah responden terbanyak adalah perempuan dengan jumlah 67 orang $(67 \%)$.

Tabel 2. Karakteristik responden berdasarkan status pekerjaan.

\begin{tabular}{lcc}
\hline \multirow{2}{*}{ Pekerjaan } & Frekuensi & Persentase \\
\cline { 2 - 3 } & $\mathbf{( n )}$ & $\mathbf{( \% )}$ \\
\hline Dosen & 16 & 16 \\
Tenaga non & 25 & 25 \\
dosen/staff & 59 & 59 \\
Mahasiswa & 100 & 100 \\
Total &
\end{tabular}

Berdasarkan pada tabel 2 dapat dilihat bahwa sebagian besar responden pada saat dilakukan observasi adalah mahasiswa dengan jumlah 59 orang (59\%).

Tabel 3. Distribusi frekuensi pelaksanaan mencuci dengan kriteria menggunakan sabun dan air mengalir atau hand sanitizer sebelum masuk ke lingkungan fakultas.

\begin{tabular}{lcc}
\hline $\begin{array}{l}\text { Mencuci tangan } \\
\text { dengan sabun dan } \\
\text { air mengalir atau } \\
\text { hand sanitizer }\end{array}$ & $\begin{array}{c}\text { Jumlah } \\
\text { (n) }\end{array}$ & $\begin{array}{c}\text { Persentase } \\
(\%)\end{array}$ \\
$\begin{array}{l}\text { sebelum masuk ke } \\
\text { lingkungan fakultas }\end{array}$ & & \\
\hline Ya & 34 & \\
Tidak & 66 & 66 \\
Jumlah & 100 & 100 \\
\hline
\end{tabular}

Berdasarkan pada tabel 3 bahwa jumlah responden terbanyak adalah yang tidak melaksanakan cuci tangan sebelum masuk ke lingkungan fakultas sebesar 66 orang $(66 \%)$.
Tabel 4. Distribusi frekuensi pelaksanaan mencuci dengan kriteria menggunakan sabun dan air mengalir atau hand sanitizer setelah berkunjung dari lingkungan fakultas.

\begin{tabular}{|c|c|c|}
\hline $\begin{array}{l}\text { Mencuci tangan } \\
\text { dengan sabun dan } \\
\text { air mengalir atau } \\
\text { hand sanitizer } \\
\text { setelah berkunjung } \\
\text { dari fakultas }\end{array}$ & $\begin{array}{c}\text { Jumlah } \\
\text { (n) }\end{array}$ & $\begin{array}{c}\text { Persentase } \\
(\%)\end{array}$ \\
\hline $\mathrm{Ya}$ & 32 & 32 \\
\hline Tidak & 68 & 68 \\
\hline Jumlah & 100 & 100 \\
\hline
\end{tabular}

Berdasarkan tabel 4 maka diketahui bahwa jumlah responden terbanyak yang tidak melaksanakan cuci tangan setelah berkunjung dari lingkungan fakultas sebesar 68 orang $(68 \%)$.

Tabel 5. Distribusi frekuensi pelaksanaan memakai masker dengan kriteria menutup mulut, hidung dan dagu saat berada di lingkungan Fakultas Keperawatan Universitas Riau

\begin{tabular}{lcc}
$\begin{array}{l}\text { Menutup mulut, } \\
\text { hidung dan dagu } \\
\text { dengan masker sat } \\
\text { berada di } \\
\text { lingkungan }\end{array}$ & $\begin{array}{c}\text { Jumlah } \\
\text { (n) } \\
\text { fakultas }\end{array}$ & $\begin{array}{c}\text { Persentase } \\
(\%)\end{array}$ \\
\hline Ya & & \\
Tidak & & \\
Jumlah & 95 & 95 \\
\hline
\end{tabular}

Berdasarkan tabel 5 maka diketahui bahwa jumlah responden terbanyak responden yang memakai masker menutup hidung, dagu dan mulut saat berada dilingkungan fakultas sebesar 95 orang $(95 \%)$

Tabel 6. Distribusi frekuensi pelaksanaan memakai masker dengan kriteria menutup mulut, hidung dan dagu saat berinteraksi dengan civitas lainnya 


\begin{tabular}{lcc}
\hline $\begin{array}{l}\text { Menutup mulut, } \\
\text { hidung dan dagu } \\
\text { dengan masker saat }\end{array}$ & $\begin{array}{c}\text { Jumlah } \\
\text { (n) }\end{array}$ & $\begin{array}{c}\text { Persentase } \\
\text { (\%) }\end{array}$ \\
$\begin{array}{l}\text { berinteraksi dengan } \\
\text { civitas lainnya }\end{array}$ & & \\
\hline Ya & 95 & 95 \\
Tidak & 5 & 5 \\
Jumlah & 100 & 100 \\
\hline
\end{tabular}

Berdasarkan tabel 6 maka diketahui bahwa jumlah responden terbanyak yang menutup mulut dan dagu 95 orang $(95 \%)$

Tabel 7. Distribusi frekuensi pelaksanaan menjaga jarak pada dengan kriteria tidak bersalaman /berciuman/ berpelukan saat bertemu dengan Civitas Fakultas Keperawatan Universitas Riau.

\begin{tabular}{lcc}
\hline $\begin{array}{l}\text { Tidak bersalaman/ } \\
\text { berciuman/ } \\
\text { berpelukan saat } \\
\text { bertemu dengan } \\
\text { civitas Fakultas }\end{array}$ & $\begin{array}{c}\text { Jumlah } \\
(\mathbf{n})\end{array}$ & $\begin{array}{c}\text { Persentase } \\
(\%)\end{array}$ \\
$\begin{array}{l}\text { Keperawatan } \\
\text { lainnya }\end{array}$ & & \\
\hline Ya & & \\
Tidak & 100 & 100 \\
Jumlah & 0 & 0 \\
\hline
\end{tabular}

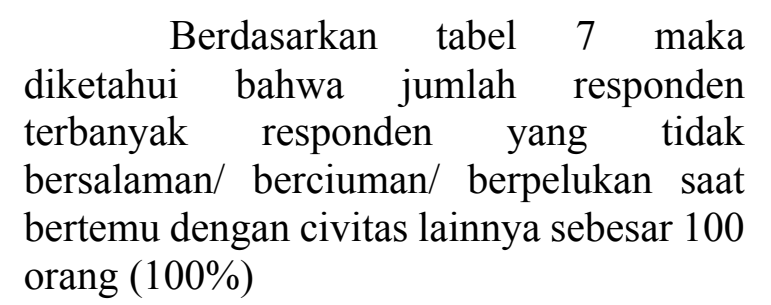

Tabel 8. Distribusi frekuensi pelaksanaan menjaga jarak dengan kriteria jarak fisik saat berinteraksi 1-2 meter.

\begin{tabular}{lcc}
\hline $\begin{array}{l}\text { Jarak fisik saat } \\
\text { berinteraksi 1-2 } \\
\text { meter }\end{array}$ & $\begin{array}{c}\text { Jumlah } \\
\text { (n) }\end{array}$ & $\begin{array}{c}\text { Persentase } \\
(\%)\end{array}$ \\
\hline Ya & 97 & 97 \\
Tidak & 3 & 3 \\
Jumlah & 100 & 100 \\
\hline
\end{tabular}

Berdasarkan tabel 8 maka diketahui bahwa jumlah responden terbanyak responden yang melaksanakan jaga jarak fisik saat berinteraksi 1-2 meter sebesar 97 orang (97\%)

Tabel 9. Distribusi frekuensi pelaksanaan menghindari kerumunan dengan kriteria tidak berkumpul-kumpul di lingkungan Fakultas.

\begin{tabular}{lcc}
\hline $\begin{array}{l}\text { Tidak } \\
\text { berkumpul- } \\
\text { kumpul di }\end{array}$ & $\begin{array}{c}\text { Jumlah } \\
\text { (n) }\end{array}$ & $\begin{array}{c}\text { Persentase } \\
\text { (\%) }\end{array}$ \\
fakultas & & \\
\hline Ya & & \\
Tidak & 97 & 97 \\
Jumlah & 3 & 3 \\
\hline
\end{tabular}

Berdasarkan tabel 9 maka diketahui bahwa jumlah responden terbanyak yang menghindari kerumunan dengan tidak berkumpul-kumpul di lingkungan fakultas sebesar 97 orang $(97 \%)$

Tabel 10. Distribusi frekuensi pelaksanaan menghindari kerumunan dengan kriteria segera meninggalkan area kampus jika telah selesai kegiatannya

\begin{tabular}{lcc}
\hline $\begin{array}{l}\text { Segera } \\
\text { meninggalkan }\end{array}$ & $\begin{array}{c}\text { Jumlah } \\
\text { (n) }\end{array}$ & $\begin{array}{c}\text { Persentase } \\
(\%)\end{array}$ \\
$\begin{array}{l}\text { kampus jika telah } \\
\text { selesai kegiatannya }\end{array}$ & & \\
\hline Ya & 100 & 100 \\
Tidak & 0 & 0 \\
Jumlah & 100 & 100 \\
\hline \multicolumn{4}{c}{ Berdasarkan tabel } & 10 & maka \\
diketahui bahwa jumlah & responden \\
terbanyak yang tidak berbagi makanan atau \\
minuman pribadi sebesar & 100 orang \\
(100\%). &
\end{tabular}

Tabel 11. Distribusi frekuensi pelaksanaan menghindari atau tidak berganti-ganti alat dan perlengkapan pribadi dengan kriteria tidak berbagi makanan atau minuman. 


\begin{tabular}{lcc}
\hline $\begin{array}{l}\text { Tidak berbagi } \\
\text { makanan atau } \\
\text { minuman }\end{array}$ & $\begin{array}{c}\text { Jumlah } \\
(\mathbf{n})\end{array}$ & $\begin{array}{c}\text { Persentase } \\
(\%)\end{array}$ \\
\hline Ya & 100 & 100 \\
Tidak & 0 & 0 \\
Jumlah & 100 & 100 \\
\hline
\end{tabular}

Berdasarkan tabel 11 maka diketahui bahwa jumlah responden terbanyak yang segera meninggalkan area kampus setelah selesai kegiatannya adalah sebesar 100 orang $(100 \%)$.

Tabel 12. Distribusi frekuensi pelaksanaan menghindari atau tidak berganti-ganti alat dan perlengkapan pribadi pada dengan kriteria tidak meminjam alat tulis, buku dan perlengkapan pribadi.

\begin{tabular}{lcc}
\hline $\begin{array}{l}\text { Tidak meminjan alat } \\
\text { tulis, buku dan } \\
\text { perlengkapan } \\
\text { pribadi lainnya. }\end{array}$ & $\begin{array}{c}\text { Jumlah } \\
(\mathbf{n})\end{array}$ & $\begin{array}{c}\text { Persentase } \\
(\%)\end{array}$ \\
\hline Ya & & \\
Tidak & 99 & 99 \\
Jumlah & 1 & 1 \\
\hline
\end{tabular}

Berdasarkan tabel 12 maka diketahui bahwa jumlah responden terbanyak yang tidak meminjam alat tulis, perlengkapan pribadi lainnya sebesar 99 orang $(99 \%)$.

\section{PEMBAHASAN}

\section{Karakteristik Responden}

Karakteristik responden berdasarkan jenis kelamin berdasarkan hasil pengamatan atau observasi yang terbanyak adalah perempuan dengan jumlah 67 orang (67\%), sedangkan responden laki-laki berjumlah 33 orang $(33 \%)$.

Wiranti (2020) mengatakan bahwa responden perempuan memiliki tingkat kepatuhan yang lebih tinggi dibandingkan laki-laki. Perempuan lebih memiliki sifat lembut, kasih sayang dan bertanggung jawab terhadap orang disekitarnya sedangkan laki-laki lebih cenderung agresif, lebih senang berpetualang, suka keleluasaan, kasar dan lebih berani mengambil resiko dibandingkan perempuan (Kurniasari, 2013). Perbedaan sifat laki- laki dan perempuan inilah yang berpengaruh terhadap komitmen untuk melaksanakan protokol Covid-19 di lingkup penyelenggaraan pendidikan atau dalam hal ini adalah Fakultas Keperawatan Universitas Riau.

Berdasarkan jenis pekerjaan.

Karakteristik responden berdasarkan pekerjaan sebagian besar adalah mahasiswa dengan jumlah 59 orang $(59 \%)$, tenaga pendidikan non dosen atau staff dengan jumlah 25 orang $(25 \%)$ dan dosen dengan jumlah 16 orang (16\%).

Menurut Webster (2020), ada beberapa faktor yang yang menyebabkan ketidakpatuhan terhadap upaya karantina kesehatan, diantaranya adalah faktor demografi dan mata pencaharian. Berdasarkan penelitian yang dilakukan oleh Ilham (2020) tentang analisis determinan kepatuhan masyarakat terhadap pelaksanaan protokol kesehatan Corona Virus Disease (Covid-19) di Kecamatan Percut Sei Tuan, Deli Serdang didapatkan hasil jenis pekerjaan sebagai guru, PNS/TNI/Polri dan pegawai swasta memiliki iklim yang kondusif untuk menerapkan protokol kesehatan Covid-19 karena adanya regulasi internal yang mengaturnya yang diterbitkan oleh peraturan pemerintah.

\section{Pelaksanaan cuci tangan pada civitas} Fakultas Keperawatan

Pelaksanaan protokol Covid-19 mencuci tangan didapatkan hasil responden yang melaksanakan cuci tangan sebelum masuk ke lingkungan fakultas sebesar 34 orang $(34 \%)$ dan yang tidak melaksanakan cuci tangan sebelum masuk ke lingkungan fakultas sebesar 66 orang (66\%). Sedangkan responden yang melaksanakan cuci tangan setelah berkunjung dari lingkungan fakultas sebesar 32 orang (32\%) dan yang tidak melaksanakan cuci tangan setelah berkunjung dari lingkungan fakultas sebesar 68 orang (68\%). 
Hasil penelitian ini sejalan dengan hasil penelitian yang dilakukan oleh Simanjuntak, Napitupulu, Wele \& Yanie (2020) terhadap warga DKI Jakarta yang menerapkan protokol Covid-19 pada periode bulan September 2021 di pelayanan publik didapatkan hasil responden yang melakukan cuci tangan atau menggunakan hand sanitizer sebesar 52.947 (80,76\%), di tempat kerja sebesar $54.127(82,6 \%)$, di mall/plaza/tempat perbelanjaan sebesar $50.928(77,68 \%)$, di pasar tradisional sebesar $33.704(51,41 \%)$, di tempat ibadah $49.321(75,23)$.

Hasil observasi yang dilakukan peneliti tidak menggambarkan secara detail perilaku pelaksanaan cuci tangan selain cuci tangan sebelum masuk ke lingkungan fakultas atau setelah berkunjung dari fakultas. Fokus dari pengamatan peneliti hanya menggambarkan pelaksanaan cuci tangan sebelum masuk kelingkungan fakultas atau setelah berkunjung dari fakultas dengan alasan keterbatasan kemampuan peneliti dalam mengamati dalam waktu yang bersamaan dan dalam jumlah subjek pengamatan yang cukup banyak.

Pelaksanaan memakai masker pada civitas Fakultas Keperawatan

Pelaksanaan protokol Covid-19 memakai masker didapatkan hasil responden yang memakai masker menutup hidung, dagu dan mulut saat berada dilingkungan fakultas sebesar 95 orang (95\%) dan yang tidak memakai masker menutup hidung, dagu dan mulut saat berada dilingkungan fakultas 5 orang (5\%). Sedangkan responden yang memakai masker menutup hidung, dagu dan mulut saat berinteraksi dengan civitas lainnya sebesar 95 orang (95\%) dan yang tidak memakai masker menutup hidung, dagu dan mulut saat berinteraksi dengan civitas lainnya sebesar 5 orang (5\%).

Data dari Badan Pusat Statistik (2020) menyatakan bahwa salah satu penyebab kenapa tidak menerapkan protokol Covid-19 dengan memakai masker adalah karena harga masker, faceshield dan alat pelindung diri yang cenderung mahal. Hasil observasi tentang pelaksanaan protokol Covid-19 tentang memakai masker, masih ada 5 orang $(5 \%)$ yang tidak memakai masker menutup hidung, dagu dan mulut saat berada dilingkungan fakultas dan 5\% yang tidak memakai masker menutup hidung, dagu dan mulut saat berinteraksi dengan civitas lainnya. Peneliti kemudian melakukan observasi apakah fakultas memfasilitasi masker secara cuma-cuma kepada para civitas yang barangkali lupa untuk membawa masker. Dari hasil observasi didapatkan fakultas belum menyediakan masker secara gratis yang bisa dipakai oleh para civitas yang tidak membawa masker.

Pelaksanaan menjaga jarak pada civitas Fakultas Keperawatan

Pelaksanaan menjaga jarak pada civitas Fakultas Keperawatan di dapatkan responden yang tidak bersalaman/berciuman/berpelukan saat bertemu dengan civitas lainnya sebesar 100 orang (100\%) dan yang bersalaman/berciuman/berpelukan saat bertemu dengan civitas lainnya sebesar 0 orang $(0 \%)$ sedangkan responden yang melaksanakan jaga jarak fisik saat berinteraksi 1-2 meter sebesar 97 orang $(97 \%)$ dan responden yang tidak melaksanakan jaga jarak fisik saat berinteraksi 1-2 meter sebesar 3 orang $(3 \%)$.

Hasil observasi tentang pelaksanaan protokol Covid-19 tentang jaga jarak fisik masih ada 3 orang (3\%) yang tidak melaksanakan atau menerapkannya. Hal ini ditemukan pada taman baca didepan gedung dekanat Fakultas Keperawatan, hal ini diakibatkan oleh faktor desain tempat duduk yang masih memungkinkan untuk duduk dalam jarak yang berdekatan baik itu dari segi ukuran atau dari segi bentuk atau jenis tempat duduk. Agar pengaturan jarak fisik bisa lebih maksimal sebaiknya dilakukan pengontrolan jarak fisik dengan melibatkan pihak pengawas seperti pihak keamanan fakultas serta memasang media KIE berupa 
standing banner atau poster jaga jarak fisik dan pembuatan marka atau tanda silang pengaturan jarak pada tempat duduk atau dengan mengganti tempat duduk dengan bentuk atau desain yang bisa memungkinkan untuk dilaksanakannnya jaga jarak di taman baca.

\section{Pelaksanaan menghindari kerumunan pada civitas Fakultas Keperawatan}

Pelaksanaan menghindari atau tidak meminjam perlengkapan pribadi pada civitas Fakultas Keperawatan didapatkan responden yang tidak berbagi makanan atau minuman pribadi sebesar 100 orang $(100 \%)$. Sedangkan responden yang tidak meminjam alat tulis, buku dan perlengkapan pribadi lainnya sebesar 99 orang $(99 \%)$ dan yang meminjam alat tulis, buku dan perlengkapan pribadi lainnya sebesar 1 orang (1\%).

Hasil observasi tentang pelaksanaan protokol Covid-19 tentang menghindari kerumunan masih ada 3 orang (3\%) yang tidak melaksanakan atau menerapkannya. Hal ini ditemukan di gerai layanan terpadu. Tampak mahasiswa berkerumun dan tidak menjaga jarak, hal ini diakibatkan oleh faktor tidak adanya marka penanda jarak baik itu dilantai atau belum adanya standing line pengatur jarak. Agar kerumunan bisa dihindari lebih sebaiknya dilakukan pemasangan marka penanda baik dilantai atau pun dengan memasang standing line dan memasang media KIE seperti standing banner tentang menghindari kerumunan.

Pelaksanaan menghindari atau tidak meminjam perlengkapan pribadi pada civitas Fakultas Keperawatan

Pelaksanaan menghindari atau tidak meminjam perlengkapan pribadi pada civitas Fakultas Keperawatan didapatkan responden yang tidak berbagi makanan atau minuman pribadi sebesar 100 orang $(100 \%)$. Sedangkan responden yang tidak meminjam alat tulis, buku dan perlengkapan pribadi lainnya sebesar 99 orang $(99 \%)$ dan yang meminjam alat tulis, buku dan perlengkapan pribadi lainnya sebesar 1 orang $(1 \%)$.
Hasil observasi didapatkan masih ada 1 orang (1\%) yang meminjam alat pribadi dalam hal ini adalah alat tulis atau pena. Hal ini masih menimbulkan peluang terjadinya penularan. Agar tidak terjadi penularan melalui transmisi meminjam alat.

\section{KESIMPULAN}

Hasil penelitian ini menunjukkan gambaran pelaksanaan protokol Covid-19 pada civitas Fakultas Keperawatan Universitas Riau di Era New Normal sudah cukup baik namun masih belum optimal yaitu terdapat di pelaksanaan cuci tangan sebelum masuk ke lingkungan fakultas dan setelah berkunjung dari lingkungan fakultas.

\section{SARAN}

Hasil penelitian ini diharapkan menjadi referensi tentang penerapan atau pelaksanaan protokol Covid-19 dilingkup penyelenggaraan pendidikan keperawatan.

\section{DAFTAR PUSTAKA}

Badan Pusat Statistik. (2020). Perilaku masyarakat di masa pandemi covid19. Diperoleh dari https://www.bps.go.id. Diakses tanggal 5 Maret 2021.

Burhan, E. (2020). Covid-19. Gejala klinis dan pengobatannya. Departemen Pulmonologi dan Kedokteran Respirasi FKUI: RS Persahabatan.

Cahyorini. (2020). Pengetahuan, sikap dan perilaku hidup sehat masyarakat dalam menghadapi pandemi covid19 di indonesia. Diperoleh dari http://jurnal.balitbang.sumutprov.go. id. Diakses tanggal 19 Agustus 2020.

CDC. (2020). Guidance for businesess and employers responding to coronavirus disease 2019 (covid-19). Centers for cDisease Control and Prevention.

Dinas Kesehatan Provinsi Riau. (2021). Update covid-19 provinsi riau. Diperoleh dari https://corona.riau.go.id. Diakses tanggal 24 Januari 2021. 
Direktorat Jenderal Pencegahan dan Pengendalian Penyakit. (2020). Pedoman pencegahan dan pengendalian coronavirus disease (covid-19). Rev. 4. Jakarta: Kementerian Kesehatan Republik Indonesia.

Kementerian Kesehatan RI. (2020). Peraturan menteri kesehatan republik indonesia nomor 9 tahun 2020 tentang pedoman pembatasan sosial berskala besar dalam rangka percepatan penanganan corona virus disease 2019 (covid-19). Pub. L. No. 9, 13. Diperoleh dari https://covid19.go.id. Diakses tanggal 19 Agustus 2020.

Kementrian Kesehatan RI. (2020). Pedoman pencegahan dan pengendalian coronavirus disease (covid-19). Diperoleh dari https://covid19.go.id.__Diakses tanggal 19 Agustus 2020.

Kementerian Dalam Negeri RI. (2020). Pedoman manajemen bagi pemerintah daerah dalam penanganan covid-19 dan dampaknya. Diperoleh dari http://ditjenbinaadwil.kemendagri.go .id.Diakses tanggal 24 Januari 2021.

PDPI, PERKI, PAPDI, PERDATIN \& IDAI. (2020). Pedoman Tatalaksana Covid 19. Jakarta. Diperoleh dari https://www.papdi.or.id. Diakses pada tgl 20 Agustus 2020

Puslitbang Upaya Kesehatan Masyarakat. (2020). Perhatian publik dan stigma sosial terhadap pandemi covid-19 di Jabodetabek. Diperoleh dari https://www.litbang.kemkes.go.id.

Diakses tanggal 19 Agustus 2020.

Simanjuntak, Napitupulu, Wele \& Yanie. (2020). Gambaran kepatuhan masyarakat menerapkan protokol kesehatan covid-19 di tempat umum periode september 2020 di DKI Jakarta. Diperoleh dari http://repository.uki.ac.id. Diakses tanggal 5 Maret 2021.
WHO. (2020). Global surveillance for human infection with novelcoronavirus(2019-ncov). Diperoleh dari https://www.who.int. Diakses tanggal 30 Desember 2020.

Wulandari, et al. (2020). Hubungan karakteristik individu dengan pengetahuan pencegahan coronavirus disease 2019 pada masyarakat di kalimantan selatan. Diperoleh dari https://jurnal.unimus.ac.id. Diakses tanggal 12 Agustus 2020. 